\title{
The Red Sea as a Corrosive Environment: Corrosion Rates and Corrosion Mechanism of Aluminum Alloys 7075, 2024, and 6061
}

\author{
Aisha H. Al-Moubaraki $(\mathbb{D})$ and Hind H. Al-Rushud \\ Chemistry Department, Faculty of Sciences, King Abdulaziz University, Al Faisaliah Campus, Jeddah, Saudi Arabia \\ Correspondence should be addressed to Aisha H. Al-Moubaraki; ahm13988@hotmail.com
}

Received 4 November 2017; Revised 14 February 2018; Accepted 4 March 2018; Published 21 May 2018

Academic Editor: Jerzy A. Szpunar

Copyright (C) 2018 Aisha H. Al-Moubaraki and Hind H. Al-Rushud. This is an open access article distributed under the Creative Commons Attribution License, which permits unrestricted use, distribution, and reproduction in any medium, provided the original work is properly cited.

\begin{abstract}
Corrosion behavior of $\mathrm{Al}$ 7075, $\mathrm{Al}$ 2024, and $\mathrm{Al} 6061$ in the Red Sea water was studied using weight loss (WL) measurements and potentiodynamic polarization (PDP) technique. The corrosion patterns and corrosion products formed on $\mathrm{Al}$ alloys were characterized using optical photography (OP), scanning electron microscopy (SEM), and energy-dispersive spectroscopy (EDS). The results showed that WL data were consistent with bimodal model rather than the power law function and the corrosion rates exhibit a continuous decrease with exposure time. The increasing order of the Red Sea corrosivity on the studied Al alloys can be given as follows: $\mathrm{Al} 6061<\mathrm{Al} 2024<\mathrm{Al} 7075$. The results of temperature effect revealed that an increase in temperature resulted in an increase in both anodic and cathodic current density and a decrease in corrosion potential. Al 7075 was less influenced by temperature than the other alloys. Pitting corrosion was the predominant corrosion pattern detected on all Al alloy surfaces after prolonged immersion in the Red Sea water. The appearance of S peak in EDS spectra of Al 7075 after corrosion gives an indication of the contribution of bacteria in the corrosion process.
\end{abstract}

\section{Introduction}

Desirable properties of aluminum such as low density (only $2.7 \mathrm{~g} / \mathrm{cm}^{3}$ ), recyclability, thermal and electrical conductivity, and, in some degree, corrosion resistance, make aluminum the most consumed nonferrous metal in the world [1]. Aluminum is often alloyed with other elements to improve its mechanical properties and increase its usefulness [2]. Commercially wrought aluminum alloys are classified into different series depending on their principle alloying elements such as 2xxx (Al-Cu alloys), $5 x x x$ (Al-Mg alloys), 6xxx (Al-Mg-Si alloys), and 7xxx series (Al-Zn-Cu alloys). Wrought aluminum alloys are used in marine engineering applications, specifically $5 \times x x$ and $6 \times x x$ series, as in shipbuilding, coastal equipment, and desalination of seawater [35]. In fact, aluminum alloys have less corrosion resistance than pure metal; so, they are often used with an appropriate protection method $[2,3]$.

Corrosion is defined by ISO as "physicochemical interaction (usually of an electrochemical nature) between a metal and its environment which results in changes in the properties of the metal and which often leads to impairment of the function of the metal, the environment, or the technical system of which these form a part" [6]. From a thermodynamic view, a layer of aluminum oxide is formed on aluminum surface in $\mathrm{pH}$ ranges of 4 to 9 , acting as a physical barrier that separates aluminum from its environment and prevents further dissolution; but, the stability of the oxide layer can be influenced by the presence of aggressive anions in the environment such as chloride in seawater $[7,8]$. The properties of the protective oxide film can also be affected by alloying elements. Those alloying elements are present not only in aluminum solid solution but also in intermetallic (IM) particles. The microstructures of aluminum alloys are complex and highly heterogeneous compared to other alloys [9]. IM particles are randomly distributed in the alloys matrix and have different microstructures and composition than the solid solution. As a result, they have different electrochemical potentials which produce an opportunity to create microgalvanic cells between these particles and the 
TABLE 1: Percentage composition of the studied Al alloys.

\begin{tabular}{lcccccccccc}
\hline Alloy & $\mathrm{Cr}$ & $\mathrm{Cu}$ & $\mathrm{Fe}$ & $\mathrm{Mg}$ & $\mathrm{Mn}$ & $\mathrm{Si}$ & $\mathrm{Ti}$ & $\mathrm{Zn}$ & $\mathrm{Zr}$ & $\mathrm{Al}$ \\
\hline 7075 & $0.18-0.28$ & $1.2-2.0$ & 0.5 & $2.1-2.9$ & 0.3 & 0.4 & 0.2 & $5.1-6.1$ & 0.25 & Remainder \\
2024 & 0.10 & $3.8-4.9$ & 0.5 & $1.2-1.8$ & $0.3-0.9$ & 0.5 & 0.15 & 0.25 & - & Remainder \\
6061 & $0.04-0.35$ & $0.15-0.4$ & 0.7 & $0.8-1.2$ & 0.15 & $0.4-0.8$ & 0.15 & 0.25 & - & Remainder \\
\hline
\end{tabular}

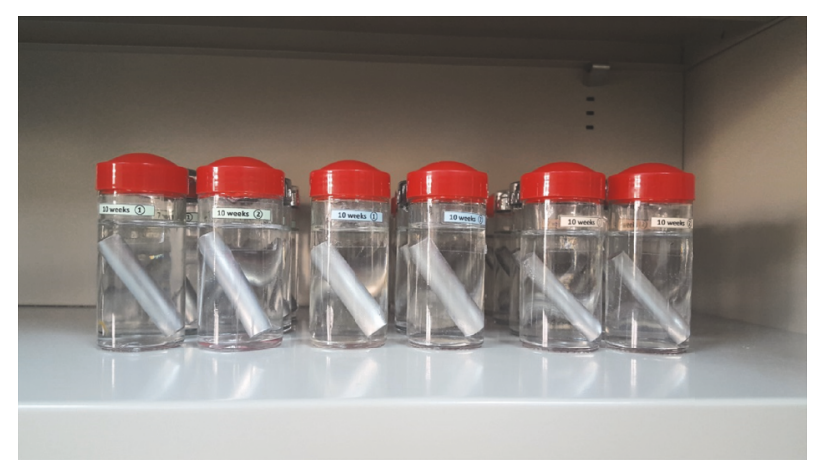

FIGURE 1: The final arrangement for weight loss experiments.

aluminum matrix $[10,11]$. Both the heterogeneous nature of alloys and presence of aggressive anions in the environments can cause loss of passivity at specific sites of aluminum alloy surface and lead to localized corrosion $[7,12,13]$. Muller and Galvele [14] studied the role of alloying elements in pitting corrosion of $\mathrm{Al}-\mathrm{Zn}, \mathrm{Al}-\mathrm{Cu}$, and $\mathrm{Al}-\mathrm{Mg}$ binary alloys in $1 \mathrm{M}$ $\mathrm{NaCl}$. It was observed that pitting potential decreased with increase in $\mathrm{Zn}$ content up to 3\%, addition of copper increased pitting potential dramatically up to $5 \%$, and $\mathrm{Mg}$ did not affect the pitting potential.

Various environmental factors such as dissolved gases, temperature, $\mathrm{pH}$, and micro- and macroorganisms can affect corrosion in seawater $[15,16]$. Most of these factors are interrelated with each other as an increase in temperature will reduce the dissolved oxygen and result in a change in biological activities; thus, evaluation of the corrosion process in seawater is complicated. Dissolved oxygen is an important factor because oxygen reduction is a primary cathodic reduction for corrosion of $\mathrm{Al}$ alloys in seawater [17]. Aluminum and its alloys have been reported to experience microbial influenced corrosion (MIC). Sulfate reducing bacteria (SRB) present in seawater is the most widely known and studied as the cause of MIC. SRB form tubercles (discrete hemispherical mounds) on aluminum surface and enhance pitting corrosion as a result of low $\mathrm{pH}$ of electrolyte under tubercles [18, 19]. In corrosion studies, seawater is often duplicated by 3.5 $\mathrm{NaCl}$ but salt concentration is not efficient to duplicate the properties of natural seawater. However, many researchers have studied the corrosion behavior of aluminum alloys in natural seawater and their results revealed that aluminum and its alloys mainly suffered from pitting corrosion in seawater [20-22]. In previous studies on aluminum corrosion by pitting, researchers distinguished between crystallographic and alkaline pitting. When cathodic intermetallic particles enhance the dissolution of the surrounding matrix, it is called alkaline pits. This type of pitting occurs below the pitting potential, while crystallographic pits are formed when an alloy reaches its pitting potential [23].
Using three different aluminum alloys (Al 7075, Al 2024, and $\mathrm{Al}$ 6061), the present research studied the Red Sea as a corrosive environment. Factors such as immersion time and temperatures on the corrosion behavior of aluminum alloys in seawater were studied using weight loss (WL) and potentiodynamic polarization (PDP) measurements. Change in aluminum alloy surfaces was detected at different conditions using optical photography (OP), scanning electron microscope (SEM), and electron-dispersive energy spectroscopy (EDS).

\section{Materials and Methods}

2.1. Materials. Three different types of aluminum alloys were used in this study. The chemical composition of aluminum alloys is given in Table 1. Specimens, 10 to $15 \mathrm{~mm}$ in diameter and 40 to $50 \mathrm{~mm}$ in length, were cut from the respective metal rods. Prior to each experiment, the exposed surfaces were scratched with a series of emery paper from 80 to 1200 grades. Then, they were washed several times with deionized water and then with ethanol and finally dried using a stream of air. The specimens were then weighed accurately and immersed in the test solution. The test solution was natural seawater and it was collected directly from the Red Sea in the western region (Obhur, Jeddah, Saudi Arabia). Several properties of the sample such as $\mathrm{pH}$, electrical conductivity, total alkalinity, and content of different ions were demonstrated in previous work [24].

\subsection{Methods}

2.2.1. Weight Loss (WL). Polished and preweighed $\mathrm{Al}$ specimens were placed in airtight glass containers containing $60 \mathrm{~mL}$ of seawater for different immersion periods $(1,2,3,5$, $7,10,22$, and 32 weeks) at an ambient temperature (laboratory temperature was $21 \pm 1^{\circ} \mathrm{C}$ ) under stagnant conditions. To facilitate the identification of specimens immersed in the seawater at different conditions, numbered stickers were used in each case (Figure 1). At the end of each immersion period, 
TABLE 2: Weight loss and corrosion rates of $\mathrm{Al}$ alloys at different immersion periods in the Red Sea water.

\begin{tabular}{|c|c|c|c|c|c|c|}
\hline \multirow{2}{*}{$\begin{array}{l}\text { Immersion period } \\
\text { (weeks) }\end{array}$} & \multicolumn{3}{|c|}{ Weight loss $\left(\mathrm{g} \mathrm{m}^{-2}\right)$} & \multicolumn{3}{|c|}{ Corrosion rate, $\mathrm{CR}_{\mathrm{WL}}\left(\mathrm{g} \mathrm{m}^{-2}\right.$ year $\left.^{-1}\right)$} \\
\hline & $\mathrm{Al} 7075$ & $\mathrm{Al} 2024$ & $\mathrm{Al} 6061$ & $\mathrm{Al} 7075$ & $\mathrm{Al} 2024$ & $\mathrm{Al} 6061$ \\
\hline 1st & 0.733 & 0.463 & 0.312 & 38.184 & 24.111 & 16.247 \\
\hline 2nd & 1.227 & 0.781 & 0.539 & 31.956 & 20.328 & 14.034 \\
\hline $3 \mathrm{rd}$ & 1.685 & 0.820 & 0.648 & 29.313 & 14.269 & 11.268 \\
\hline 5 th & 2.284 & 1.721 & 0.997 & 23.813 & 17.950 & 10.392 \\
\hline 7 th & 2.366 & 1.891 & 1.094 & 17.630 & 14.088 & 8.150 \\
\hline 10th & 2.396 & 1.994 & 1.147 & 12.490 & 10.394 & 5.981 \\
\hline 22nd & 3.826 & 2.567 & 1.663 & 9.069 & 6.084 & 3.942 \\
\hline 32nd & 4.173 & 3.241 & 1.880 & 6.796 & 5.279 & 3.062 \\
\hline
\end{tabular}

the specimens were assessed by weight loss measurement. Layers of corrosion products were scraped off the Al surfaces with a bristle brush and immediately immersed in the pickling solution containing concentrated nitric acid (86\%) for five minutes (ASTM G1) [25]. After corrosion products were completely removed, the specimens were rinsed with deionized water and ethanol, dried with a stream of air, and reweighed to determine weight loss. Duplicate experiments were conducted for all the weight loss experiments. The corrosion rate $\left(\mathrm{CR}_{\mathrm{WL}}\right)$ was calculated in $\mathrm{g} / \mathrm{m}^{2}$ year according to the following equation:

$$
\mathrm{CR}_{\mathrm{WL}}\left(\mathrm{g} / \mathrm{m}^{2} \text { year }\right)=\frac{\Delta W}{A t},
$$

where $\Delta W$ is weight loss in grams $(\mathrm{g}), A$ is area in square meters $\left(\mathrm{m}^{2}\right)$, and $t$ is the exposure time in year.

2.2.2. Potentiodynamic Polarization (PDP). Potentiodynamic polarization measurements were performed in a threeelectrode cell. A cylinder specimen of $\mathrm{Al}$ alloys was used as working electrode and was embedded in a Teflon holder using epoxy resin, giving an exposed area of 0.699 to $1.269 \mathrm{~cm}^{2}$. Platinum mesh was used as the counter electrode and silver/silver chloride $(\mathrm{Ag} / \mathrm{AgCl}(\mathrm{s}) / \mathrm{KCl}$ saturated (aq)) was used as the reference electrode. Potentiodynamic polarization measurements were done using ACM Gill AC Potentiostat/Galvanostat model 1649 connected to a personal computer. Prior to each experiment, the working electrode was treated as described in the weight loss method and then dipped in the test solution. After reaching a steady-state potential, the potentiodynamic curves were carried out by changing, linearly, the electrode potential from the starting potential $(-1200 \mathrm{mV})$ with respect to the reference electrode towards a less negative direction with the required scan rate $(1 \mathrm{mV} / \mathrm{s})$ till the end of the experiment at $-200 \mathrm{mV}$. All the electrochemical measurements were done twice at different conditions. Corrosion current densities were determined by extrapolation of cathodic Tafel line to corrosion potential using the ACM Gill software.

\subsection{Surface Examination Study}

2.3.1. Optical Photograph. Optical photographs of Al alloy specimens were taken after the chemical experiments, to evaluate gross changes in the metal surface and to perform a cursory evaluation of the forms of corrosion (e.g., general, pitting) at different conditions. Optical photographs were taken using VMS-004 USB microscope.

2.3.2. SEM-EDS Measurement. The scanning electron microscopy (SEM) associated with the energy-dispersive $\mathrm{X}$ ray spectroscopy (EDS) was used to investigate the surface morphology of aluminum alloys and analyze the elements on the surfaces of alloys before and after immersion in seawater for five weeks.

\section{Results and Discussion}

\subsection{Weight Loss}

3.1.1. Time Dependence of Corrosion Rate. Table 2 and Figure 2 give the weight loss and corrosion rates $\left(\mathrm{CR}_{\mathrm{WL}}\right)$ of $\mathrm{Al}$ alloys at different immersion periods in the Red Sea water. The results showed that weight loss increased (Figure 2(a)), while the corrosion rates decreased (Figure 2(b)) with increase in time of exposure. Decrease in corrosion rates with time is frequently observed in many types of environments [26-28] and is caused by the gradual build-up of a thicker and more protective layer. This layer is not truly passivating as it acts as a membrane, especially in the presence of aggressive ions such as the $\mathrm{Cl}^{-}$ions. If $\mathrm{Cl}^{-}$ions are present in the aqueous phase, they can penetrate the corrosion product layer and corrode the $\mathrm{Al}$ alloys (increase in weight loss value), although at a reduced rate [24]. The results indicate that the CRs depend on the composition of the studied Al alloys. Sinyavskii and Kalinin [21] reported that if cathodic additives and impurities in aluminum alloys such as $\mathrm{Cu}$ and $\mathrm{Fe}$ increase, the susceptibility to localized corrosion increases. This explains the poor corrosion resistance of Al 7075 and Al 2024 and high corrosion resistance of Al 6061 alloy. Zinc 


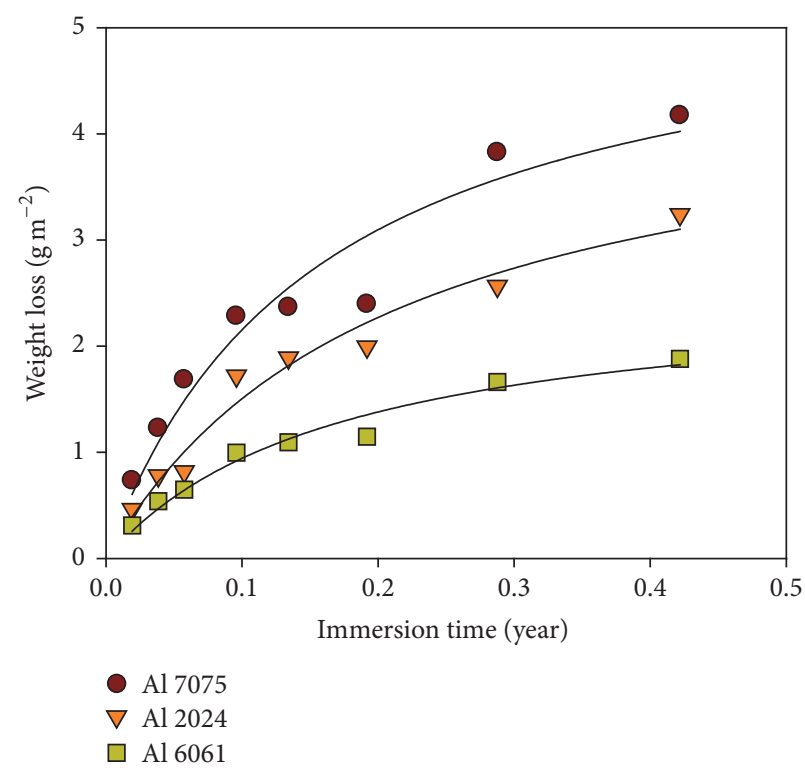

(a)

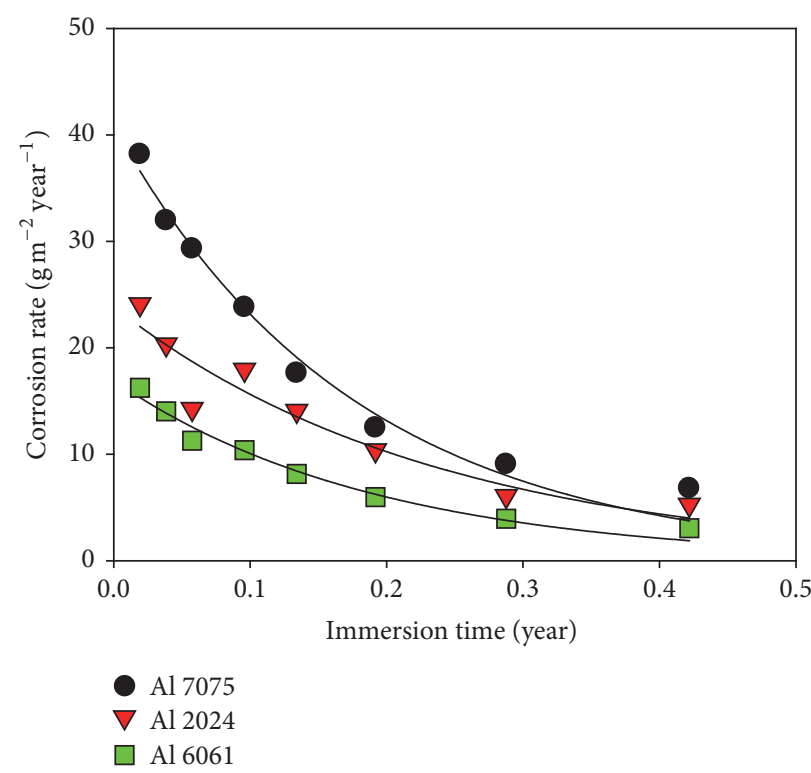

(b)

FIgURE 2: Dependence of weight loss and corrosion rates of Al alloys in the Red Sea water on immersion time.

content in $\mathrm{Al} 7075$ reduced its corrosion resistance and led to higher corrosion rate. According to the corrosion rates values, the increasing order of the Red Sea water corrosivity on the studied $\mathrm{Al}$ alloys can be given as follows.

$$
\stackrel{\text { Corrosion rate }}{\longrightarrow}
$$

$$
\mathrm{Al} 6061<\mathrm{Al} 2024<\mathrm{Al} 7075
$$

Corrosion resistance

Corrosion pattern can be monitored at different periods by visual inspection as shown in Figures 3-5. It is obvious that the alloys suffered from localized corrosion, especially pitting form. Deep and shallow pits appeared on the Al alloy surface. The samples with pitting corrosion had white sediment of corrosion products above every pit. Around the pits, there was a brighter area, which is the cathodic area where the reduction occurs. The color of the surface, the number of pits, and the spread of the pits were different for each alloy and different immersion periods. The Red Sea has a high concentration of chloride ions and according to Frankel [28], pitting corrosion will only occur in the presence of aggressive anionic species, and chloride ions are usually the cause. The severity of pitting tends to vary with the logarithm of the bulk chloride concentration [7]. The aggressiveness of chloride anion is attributed to its ability to interfere with passivation as it is a small anion with high diffusivity

3.1.2. Kinetic Study. Most of the previous data sets in corrosion studies appeared to fit the power law function (see (3)) which is derived based on the oxygen diffusion mathematics by Tammann [29]:

$$
C=A t^{n}
$$

where $C$ is corrosion loss or pit depth, $t$ is exposure time, and $A$ and $n$ are constants obtained from fitting the function to data. However, a power model involving logarithmic transformation of the immersion time and corrosion loss must be applied in order to obtain the linear form of the above equation as follows:

$$
\log C=\log A+n \log t .
$$

Figure 6 shows log-log plots for weight loss $\left(\mathrm{g} \mathrm{m}^{-2}\right)$ of $\mathrm{Al}$

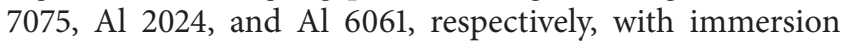
periods. The data trends of the studied alloys did not show a good fit to a straight line, so they are inconsistent with the power law function model. Melchers [30, 31] reviewed the data sets for long-term corrosion of aluminum and reported that the bimodal model appears to be applicable to long-term corrosion and the power law function is only limited to the short-term corrosion loss. The bilinear graph obtained on $\log$-log coordinates as an alternative obeys an equation of the following type $[32,33]$ :

$$
C=C_{1} t_{1}^{n_{1}-n_{2}} t^{n_{2}} \quad\left(t \geq t_{1}\right),
$$

where $C$ is the weight loss after $t$ years, $C_{1}$ is the first year weight loss, $t_{1}$ is the duration (in years) of the first exposure period, whose slope is $n_{1}$, and $n_{2}$ is the slope of the second period. One possible reason for this extraordinary behavior may lie in the formation with time of more compact layers which impede the diffusion of the reactive species that participate in the corrosion reactions. However, even though the immersion time in the current experiments did not exceed 32 weeks, the data showed that two distinct lines provide a better fit for the data of $\mathrm{Al}$ alloys than a single trend line and this is consistent with the bimodal model. The values of $C_{1}, n_{1}, n_{2}$, and correlation coefficients $\left(r_{1}^{2}\right.$ and $\left.r_{2}^{2}\right)$ are estimated and recorded in Table 3. 
TABLE 3: Corrosion kinetic parameters for $\mathrm{Al}$ alloys in the Red Sea water.

\begin{tabular}{lccc}
\hline Kinetic parameters & $\mathrm{Al} \mathrm{7075}$ & $\mathrm{Al} \mathrm{2024}$ & $\mathrm{Al} 6061$ \\
\hline$C_{1}\left(\mathrm{~g} \mathrm{~m}^{-2}\right)$ & 12.505 & 9.029 & 5.136 \\
$n_{1}$ & 0.71 & 0.763 & 0.706 \\
$n_{2}$ & 0.420 & 0.326 & 0.355 \\
$r_{1}^{2}$ & 0.997 & 0.920 & 0.992 \\
$r_{2}^{2}$ & 0.952 & 0.964 & 0.978 \\
\hline
\end{tabular}
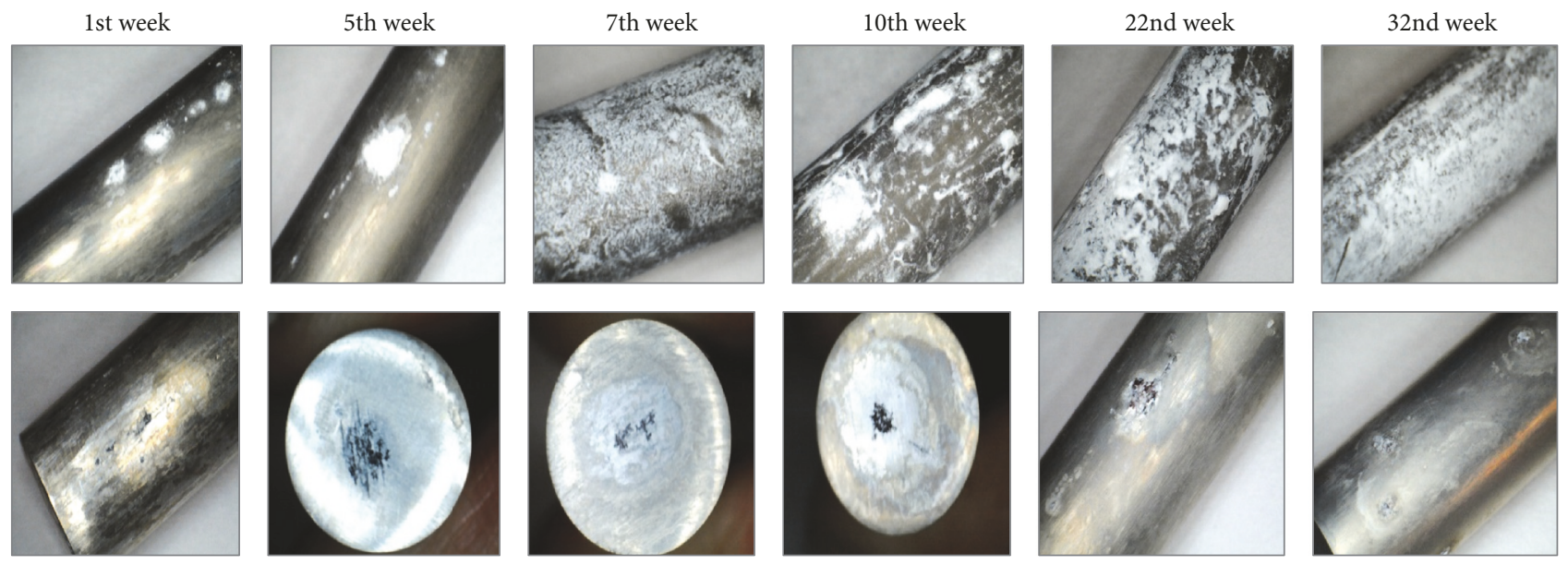

FIGURE 3: Visual images of Al 7075 specimens after immersion in the Red Sea water at different time intervals.

1st week
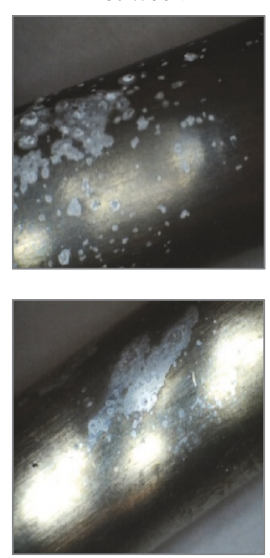

7th week
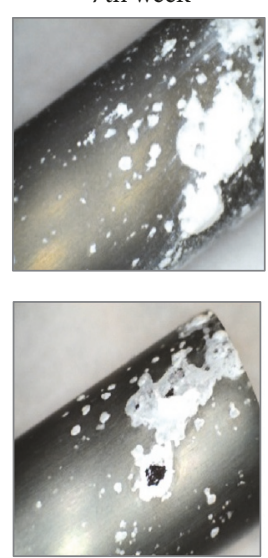

10th week
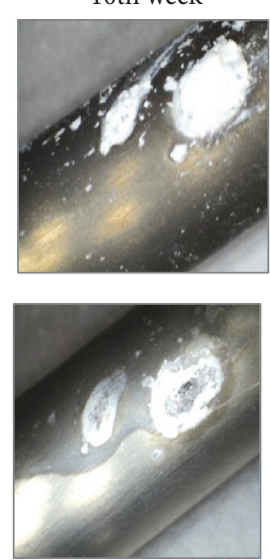
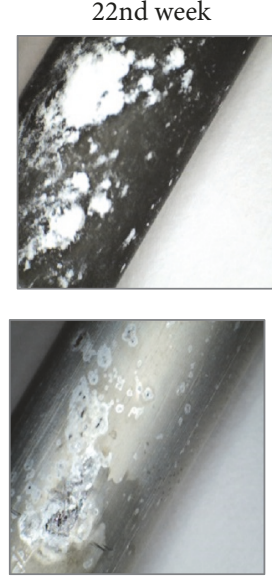

32nd week
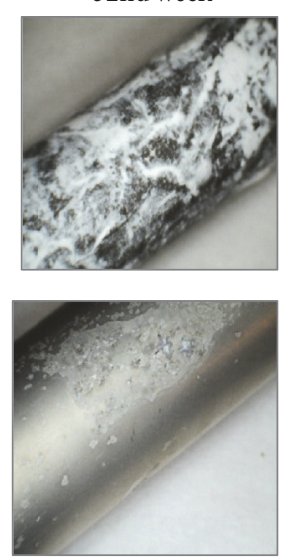

FIGURE 4: Visual images of $\mathrm{Al} 2024$ specimens after immersion in the Red Sea water at different time intervals.
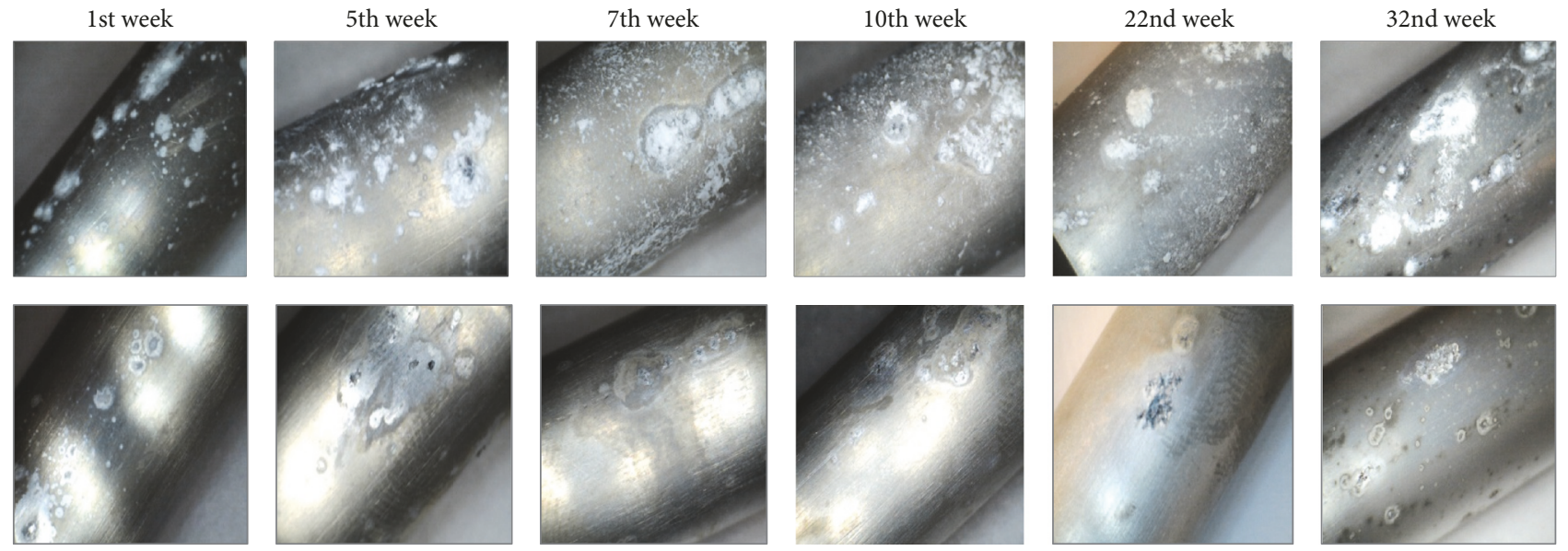

FIGURE 5: Visual images of $\mathrm{Al} 6061$ specimens after immersion in the Red Sea water at different time intervals. 

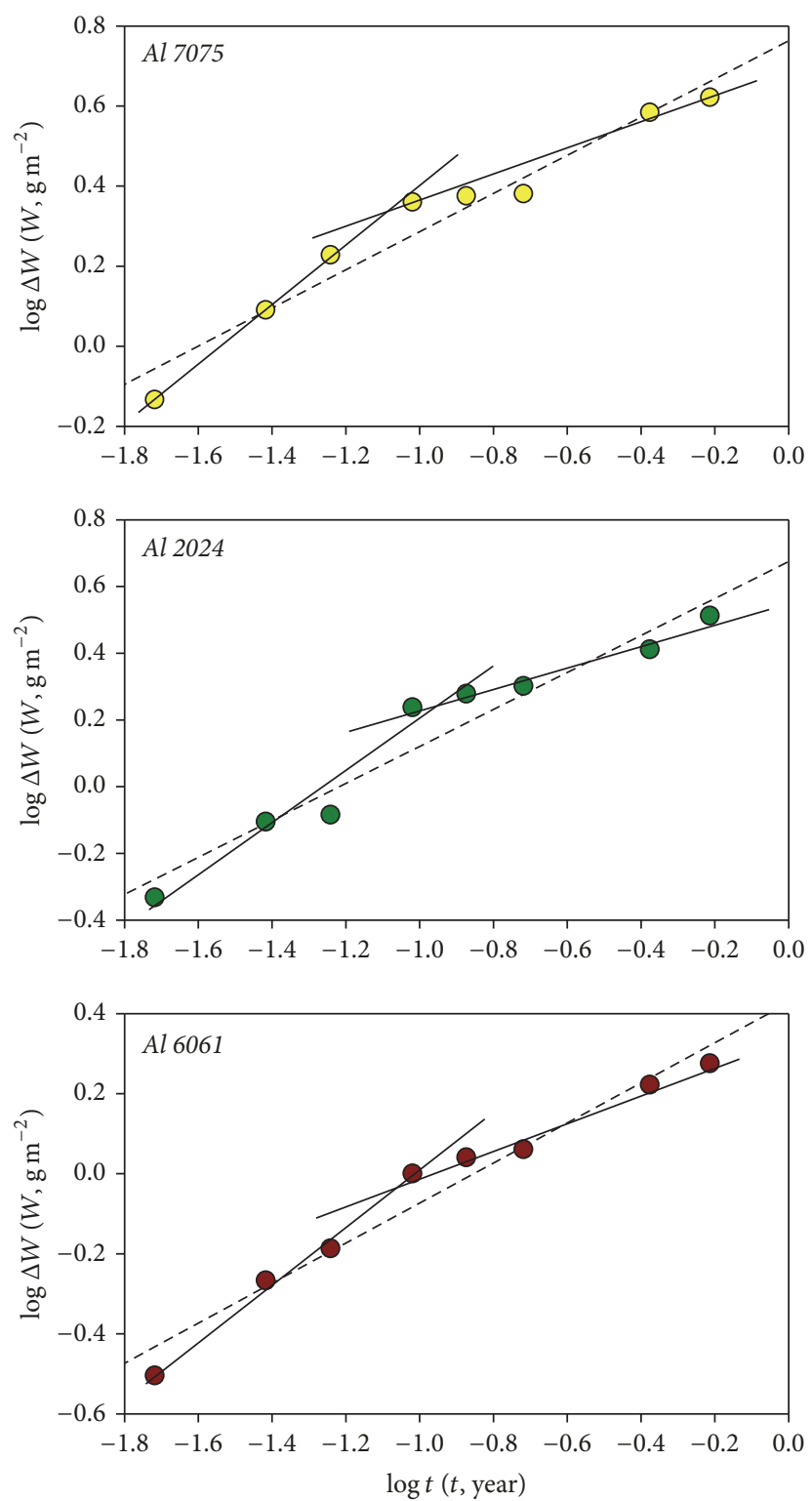

Figure 6: $\log \Delta W$ versus $\log t$ for $\mathrm{Al}$ alloys immersed in the Red Sea water.

By examining the data obtained in Table 3, the following observations were obtained:

(a) The values of weight loss after one year $\left(C_{1}\right)$ indicate that the corrosion of $\mathrm{Al}$ alloys in the Red Sea water continues to increase significantly in the same order; $\mathrm{Al} 7075$ is the highest mass loss more frequently, while $\mathrm{Al} 6061$ is the lowest mass loss.

(b) The value of $n$ can assist as an investigative tool to indicate the diffusion properties through the corrosion products that formed on the metal surface. It was found that the values of $n_{2}$ are much smaller than that of $n_{1}$. The values of $n$ can be interpreted according to the following situations [33]:

(i) When $n$ is roughly equal to 0.5 , the corrosion process is controlled by ideal diffusion process through the corrosion products that remain on the metal surface.

(ii) When $n$ is greater than 0.5 , the diffusion process is accelerated due to corrosion products detachment by cracking, dissolution, soluble complex formation, and so on.

(iii) When $n$ is less than 0.5 , the diffusion process is decreased because the corrosion products layer becomes more compact and protective on the metal surface with time.

The reason for this observation can be stated after considering the proposed mechanism of the bimodal behavior.

$$
\begin{aligned}
4 \mathrm{Al}+3 \mathrm{O}_{2}+6 \mathrm{H}_{2} \mathrm{O} \longrightarrow 4 \mathrm{Al}(\mathrm{OH})_{3} \\
2 \mathrm{Al}+3 \mathrm{H}_{2} \mathrm{O} \longrightarrow \mathrm{Al}_{2} \mathrm{O}_{3}+3 \mathrm{H}_{2} \uparrow
\end{aligned}
$$



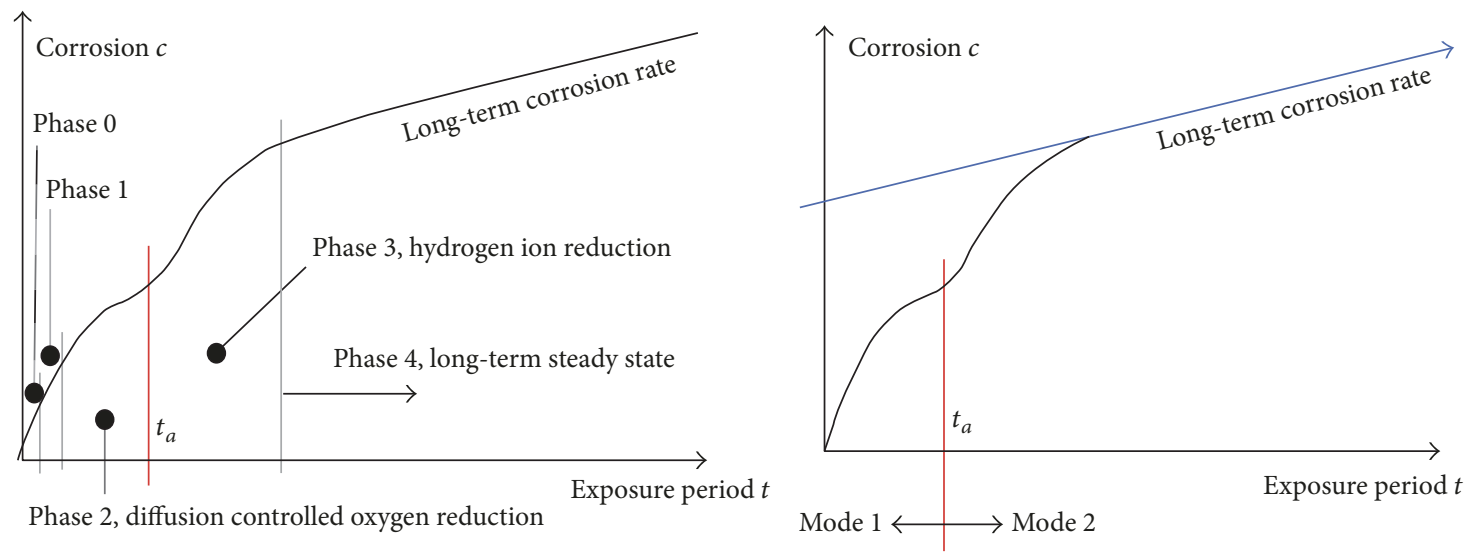

FIGURE 7: Schematic bimodal model for long-term corrosion loss and pit depth in marine environments. The change from mode 1 with predominantly oxic corrosion conditions to mode 2 with predominantly anoxic conditions occurs at $t_{a}$.

According to the above equations, reduction of oxygen and hydrogen ion is the two possible cathodic reactions. In fact, they cannot occur at the same environment conditions. For oxygen reduction, sufficient amount of oxygen must be supplied to the corroded surfaces, whereas hydrogen ion reduction can occur under anoxic conditions. Melchers Centre $[30,31]$ claimed that continuous formation of corrosion products and nonuniform topography of the corroded surface creates localized anoxic environments and permits hydrogen ion reduction. As the corrosion process progresses with time, the primary cathodic reaction changes to be hydrogen ion reduction instead of oxygen reduction. This change in cathodic reaction and, as a result, in the rate determining step, is the cause of the bimodal trend. Figure 7 shows the schematic bimodal model for corrosion loss as a function of exposure time [31]. As the first trend, a gradual decrease in corrosion rate was observed and this behavior is also represented by the power law function. The nonuniform and nonhomogeneous topography of corroding surfaces will develop as corrosion proceeds, though the thickness and properties of corrosion products on the corroding surfaces and over the pits also become nonuniform. As a result, local regions with low oxygen concentration will be produced and differential aeration cells will be established. These are sufficient conditions for the initiation and progression of pitting corrosion. Oxygen reduction is likely to occur in the shallower regions and corrosion is controlled by inward oxygen diffusion through corrosion products. As the second trend, further build-up of corrosion products will develop highly localized anoxic conditions, especially at the deeper corroded parts (pits). Hydrogen ion reduction is permitted thermodynamically under anoxic condition. In this case, corrosion rate is controlled by the outward diffusion of hydrogen gas. Hydrogen gas diffuses faster than oxygen through corrosion products (because hydrogen molecules are smaller than oxygen molecules) and an increase in corrosion rate is expected if the hydrogen ion reduction becomes the cathodic reaction in sufficient number of areas; this change in the rate trend causes the inflection in the bimodal model. In steady state, hydrogen diffusion cannot remain the rate limiting step for a long time. Other aspects have been considered as reason for the polarized equation (7). This causes a slow decline in instantaneous corrosion rate for longer term exposure such as the inward diffusion of water through the corrosion product, the outward diffusion of soluble corrosion products, or, less likely, the kinetics of the reactions. A review of the previous data revealed that a long period of time (Figure 7 line $\left(t_{a}\right)$ ) was required to permit deviation from the first trend; so, the short-term corrosion loss of data did not reach this time and was consistent with the power law function. This time can be affected by temperature, oxygen concentrations, or experimental conditions. In the current study, the weight loss experiments were carried out under stagnant conditions at laboratory temperature; this procedure kept corrosion products adherent on the alloy surfaces and high amount of corrosion products accumulated quickly on the corroded surfaces. As a result, the required time to reach the inflection point was reduced to a few weeks. This may be the reason for the observation of the bimodal model with short-immersion corrosion loss.

\subsection{Potentiodynamic Polarization (PDP)}

3.2.1. Effect of Immersion Time. Anodic curves can present useful information on passivation or depassivation of a metal dipped in solutions containing aggressive ions [34, 35]. Figure 8 shows the polarization curves for $\mathrm{Al} \mathrm{7075,} \mathrm{Al} 2024$, and $\mathrm{Al}$ 6061, respectively, in the Red Sea water after different immersion periods. Al 6061 and Al 2024 show well-defined breakdown potential at all immersion times. Passivity region or difference between corrosion potential and breakdown potential broaden as immersion time increased which may be as a result of accumulation of corrosion products during immersion and build-up of insoluble products. Polarization curves of $\operatorname{Al} 7075(2,24$, and $72 \mathrm{~h})$ show a sharp increase in the current density directly above corrosion potential. In this case, the corrosion potential of $\mathrm{Al} 7075$ was often remarked as the first breakdown potential [36]. As the immersion time 

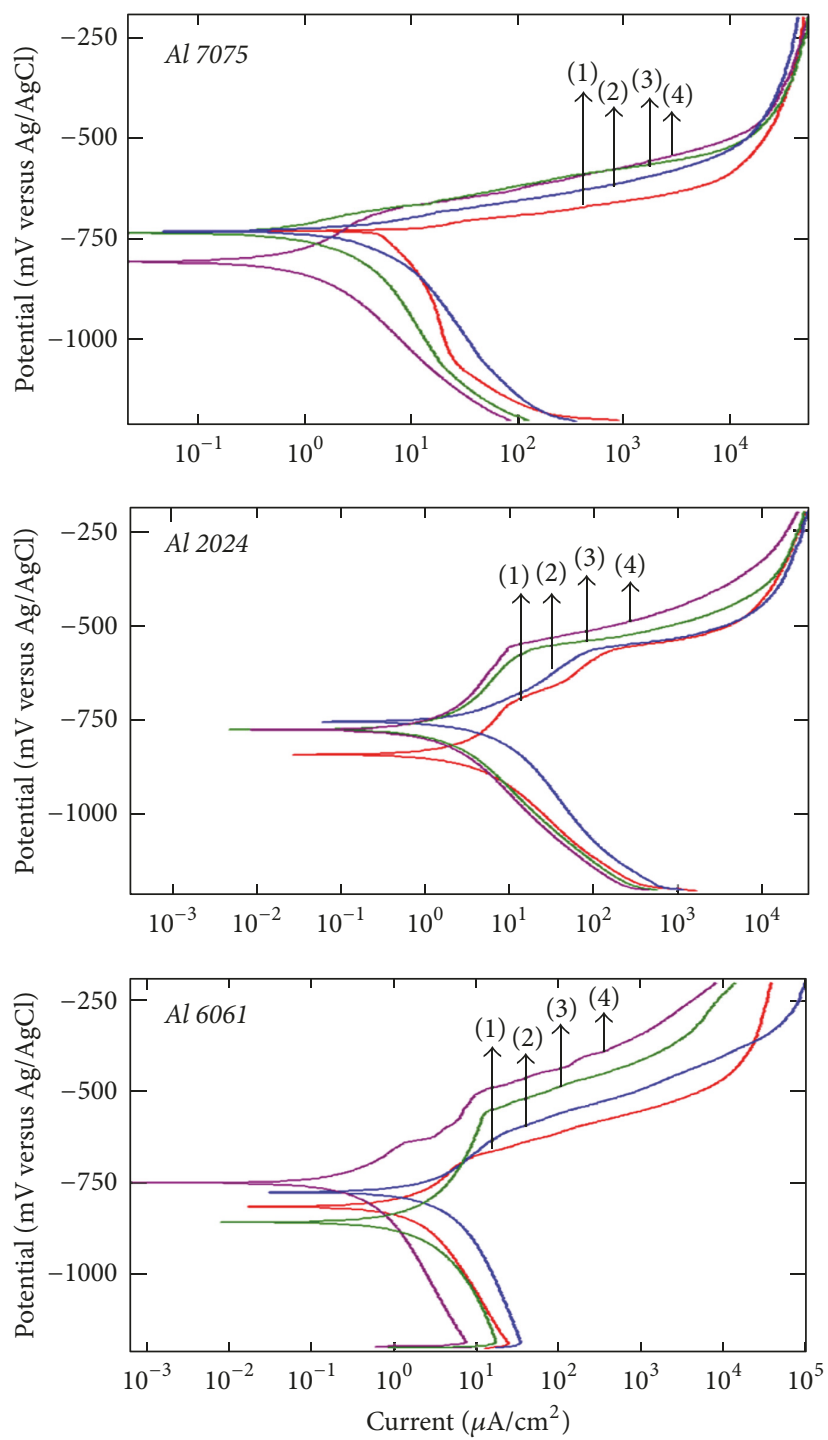
(1): 2 hours
(4): 168 hours
(2): 24 hours
(3): 72 hours

FIgURE 8: Potentiodynamic polarization curves of $\mathrm{Al}$ alloys in the Red Sea water at different time interval.

TABLE 4: Potentiodynamic polarization parameters of $\mathrm{Al}$ alloys in the Red Sea water at different immersion periods.

\begin{tabular}{|c|c|c|c|c|c|c|}
\hline \multirow{2}{*}{ Time (hours) } & \multicolumn{2}{|c|}{$\mathrm{Al} 7075$} & \multicolumn{2}{|c|}{ Al 2024} & \multicolumn{2}{|c|}{$\mathrm{Al} 6061$} \\
\hline & $-E_{\text {corr }}(\mathrm{mV})$ & $i_{\text {corr }}\left(\mu \mathrm{A} / \mathrm{cm}^{2}\right)$ & $-E_{\text {corr }}(\mathrm{mV})$ & $i_{\text {corr }}\left(\mu \mathrm{A} / \mathrm{cm}^{2}\right)$ & $-E_{\text {corr }}(\mathrm{mV})$ & $i_{\text {corr }}\left(\mu \mathrm{A} / \mathrm{cm}^{2}\right)$ \\
\hline 2 & 732 & 5.78 & 842 & 3.20 & 814 & 1.38 \\
\hline 24 & 731 & 6.29 & 757 & 4.31 & 773 & 2.28 \\
\hline 72 & 735 & 2.14 & 777 & 1.56 & 855 & 1.28 \\
\hline 168 & 806 & 1.64 & 777 & 1.19 & 749 & 0.27 \\
\hline
\end{tabular}

increased (168 h), the anodic curve of $\mathrm{Al} 7075$ exhibited small passive window and the breakdown potential was distinguished from the corrosion potential. Cathodic curves of the studied alloys shifted to less current at 72 and $168 \mathrm{~h}$ of immersion, but the shape of the cathodic curves did not change; thus, it is expected that the cathodic reaction mechanism remains the same over all immersion times. The electrochemical parameters such as $E_{\text {corr }}$ and $i_{\text {corr }}$ were estimated and listed in Table 4. The influence of immersion time on the above electrochemical parameters is discussed in the following.

(i) The values of $i_{\text {corr }}$ tend to increase as immersion time increases, up to a maximum time of $24 \mathrm{~h}$ and then 
TABLE 5: Corrosion potential $E_{\text {corr }}(\mathrm{mV})$ and breakdown potential $E_{b}(\mathrm{mV})$ of aluminum alloys at different temperature.

\begin{tabular}{lcccccc}
\hline \multirow{2}{*}{ Temperature $\left({ }^{\circ} \mathrm{C}\right)$} & \multicolumn{2}{c}{$\mathrm{Al} \mathrm{7075}$} & \multicolumn{2}{c}{$\mathrm{Al} \mathrm{2024}$} & \multicolumn{2}{c}{$\mathrm{Al} \mathrm{6061}$} \\
& $-E_{\text {corr }}(\mathrm{mV})$ & $-E_{b}(\mathrm{mV})$ & $-E_{\text {corr }}(\mathrm{mV})$ & $-E_{b}(\mathrm{mV})$ & $-E_{\text {corr }}(\mathrm{mV})$ & $-E_{b}(\mathrm{mV})$ \\
\hline 10 & 715 & - & 797 & 708 & 781 & 700 \\
25 & 732 & - & 842 & 708 & 814 & 695 \\
45 & 793 & 691 & 909 & 704 & 978 & 689 \\
60 & 956 & 685 & 968 & 677 & 1035 & 628 \\
\hline
\end{tabular}

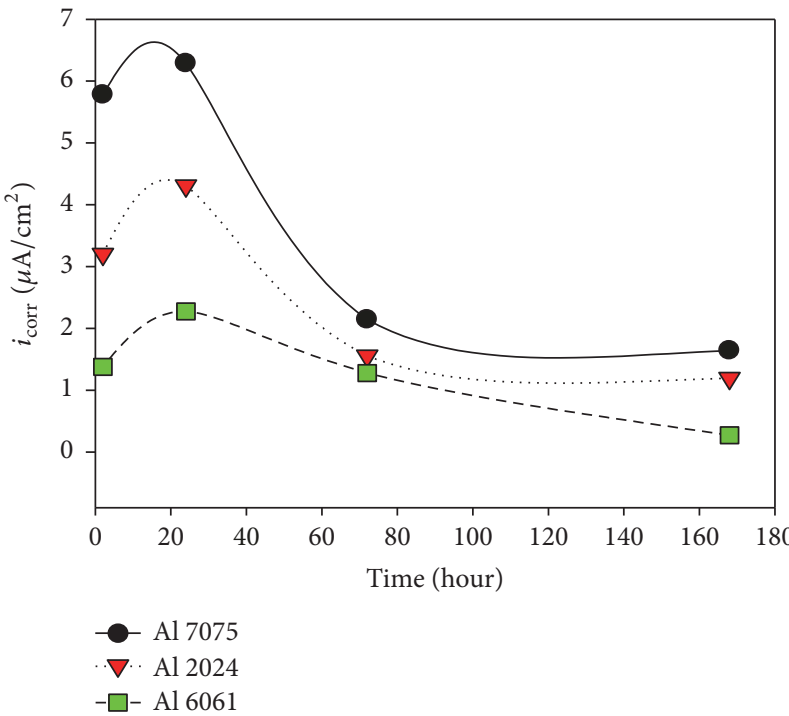

(a)

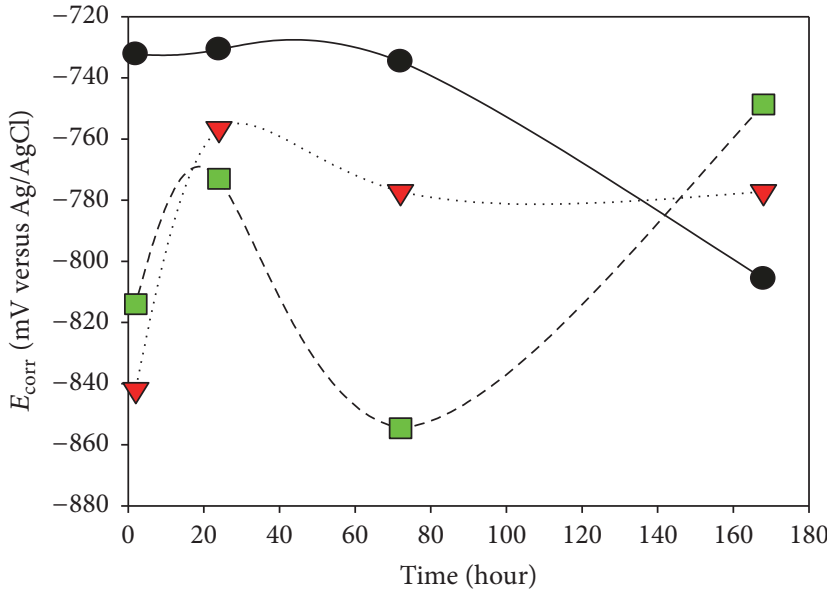

$\mathrm{Al} 7075$

$\mathrm{Al} 2024$

$\mathrm{Al} 6061$

FIGURE 9: Variation of (a) $i_{\text {corr }}$ and (b) $E_{\text {corr }}$ with immersion periods.

tend to decrease at immersion time more than $24 \mathrm{~h}$, as shown in Figure 9(a). The decrease in $i_{\text {corr }}$ with immersion time may be attributed to the formation of a protective layer of corrosion products, composed of mainly less soluble aluminum compounds. According to $i_{\text {corr }}$ values, $\mathrm{Al} 7075$ has the highest corrosion current, while $\mathrm{Al} 6061$ has the lowest corrosion current density at all immersion times. They resist corrosion in an order like that obtained previously from chemical studies:

$$
\mathrm{Al} 6061>\mathrm{Al} 2024>\mathrm{Al} 7075
$$

(ii) Figure 9(b) shows no definite trend for $E_{\text {corr }}$ values. Although the corrosion products are quickly formed on the Al surface, they take a considerably longer time to reach a steady state which is not seen in PDP measurements. The times of immersion included in the PDP study are not sufficient to reach steady state.

3.2.2. Effect of Temperature. Polarization curves of $\mathrm{Al} 7075$, $\mathrm{Al} 2024$, and $\mathrm{Al} 6061$ immersed in the Red Sea water for $2 \mathrm{~h}$ were recorded as a function of temperature and are presented in Figure 10. Temperature affects chemical kinetics of the corrosion reaction and enhances cathodic reaction by increasing oxygen diffusion. The examination of polarization responses of aluminum alloys revealed a continuous increase in both anodic and cathodic current density and a decrease in corrosion potential with increase in temperature. Table 5 shows corrosion potential $E_{\text {corr }}$ and breakdown potential $E_{b}$ of the studied alloys at different temperatures.

The obtained results can be interpreted as follows:

(i) $E_{\text {corr }}$ values shifted to more negative values with increase in temperatures, indicating that, with increase in the Red Sea water temperatures, the corrosion process comes under cathodic control. Increasing the temperature will increase the rate of oxygen diffusion to the metal surface, thus increasing corrosion current density (Figure 11(a)) because more oxygen is available for the cathodic reduction process. In the current study, this fact did not conflict with the fact that increasing temperature reduces oxygen solubility, because the studied temperatures did not exceed $80^{\circ} \mathrm{C}$ and the studied systems are closed, whereby oxygen was unable to escape; so, corrosion continued to increase with temperature [37]. 

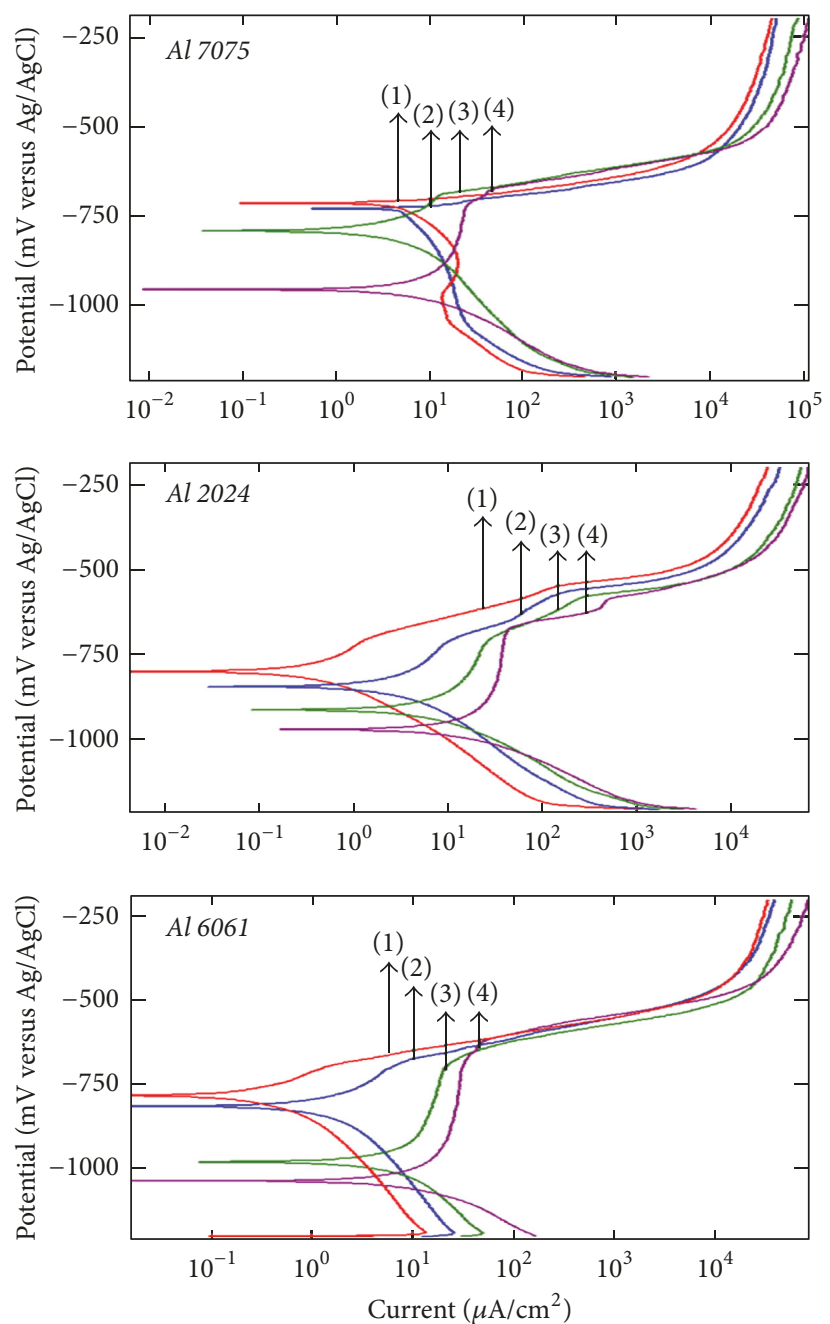
(1): $10^{\circ} \mathrm{C}$
(4): $60^{\circ} \mathrm{C}$
(2): $25^{\circ} \mathrm{C}$
(3): $45^{\circ} \mathrm{C}$

FIGURE 10: Potentiodynamic polarization curves of $\mathrm{Al}$ alloys in the Red Sea water at different temperatures.

(ii) It is shown that lowering corrosion potentials was accompanied by raising breakdown potential $\left(E_{b}\right)$ which resulted in expanding the passive region $\Delta E$ of all alloys (Figure 11(b)), especially at high temperatures $\left(45^{\circ} \mathrm{C}\right.$ and $\left.60^{\circ} \mathrm{C}\right)$. Increasing passivation with temperatures was also reported in a previous work [38]. However, increase in passivity region did not result in decrease in the current density. Immersion of alloys in the Red Sea water for $2 \mathrm{~h}$ at high temperature resulted in high reaction rate and formation of more amounts of corrosion products. Since a thick barrier of corrosion products is considered as a type of passivation [18], the presence of more corrosion products on alloys surfaces may be the reason for promoting the passivity. One other possible reason is that increased temperature leads to rapid dissolution of active elements ( $\mathrm{Mg}$ and $\mathrm{Al}$ ) from S-phase particles $\left(\mathrm{Al}_{2} \mathrm{CuMg}\right)$, leaving $\mathrm{Cu}$-rich regions on the alloys surfaces that may increase breakdown potentials with temperature $[39,40]$.

(iii) Al 7075 experienced the highest current density followed by $\mathrm{Al} 2024$ and then $\mathrm{Al} 6061$ at all temperatures with the exception of $60^{\circ} \mathrm{C}$; $\mathrm{Al} 2024$ exhibited higher corrosion current than $\mathrm{Al} 7075$. Figure 12 reveals how the order of corrosion current density at Tafel region of the studied $\mathrm{Al}$ alloys changed at high temperature $60^{\circ} \mathrm{C}$ compared to low temperature $25^{\circ} \mathrm{C}$. Other researchers [17] also found that $\mathrm{Al} 2024$ exhibited higher cathodic current density in chloride solution than Al 7075 and they related this order by the number of cathodic active IM particles. Numbers of catholically active $\mathrm{Cu}$-containing IM particles increased in this order: Al $6061<\mathrm{Al} 7075<\mathrm{Al} 2024$. Corrosion current rate of $\mathrm{Al} 7075$ was less influenced by temperature than $\mathrm{Al} 6061$ and $\mathrm{Al} 2024$; Cavanaugh 


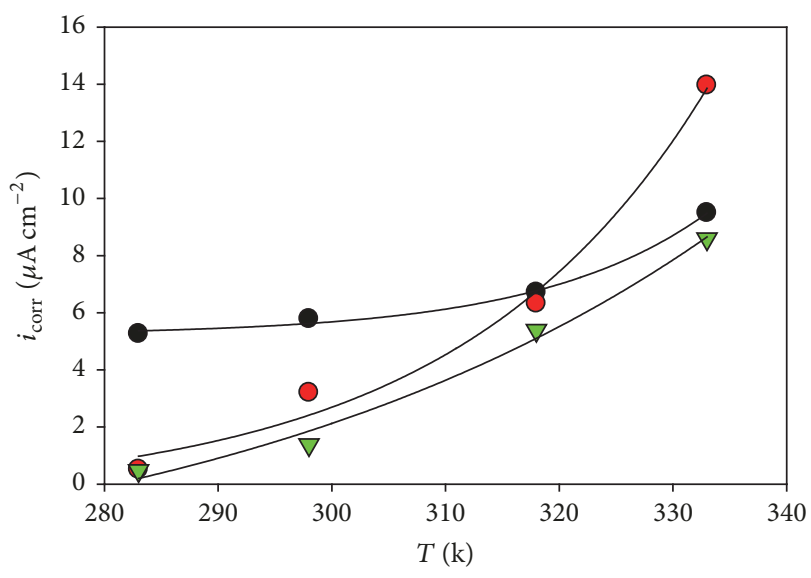

- $\mathrm{Al} 7075$

- $\mathrm{Al} 2024$

$\nabla \mathrm{Al} 6061$

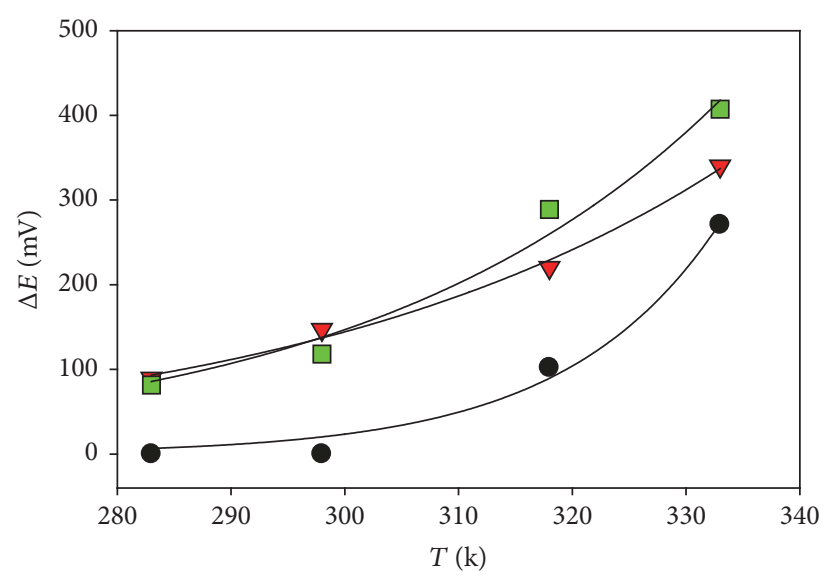

- Al 7075

$\nabla$ Al 2024

$\square \mathrm{Al} 6061$

(a)

(b)

FIGURE 11: Dependence of (a) $i_{\text {corr }}$ and (b) $\Delta E$ of Al alloys in the Red Sea water on temperature.
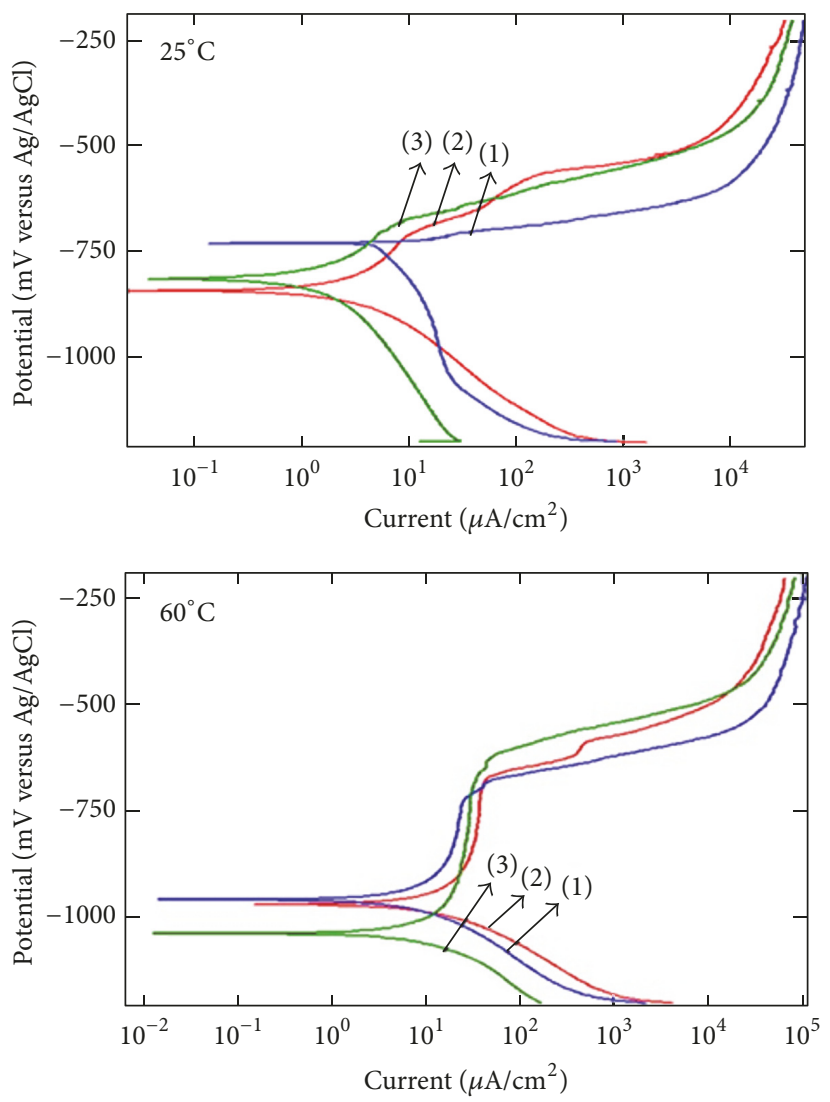

(1): $\mathrm{Al} 7075$

(2): $\mathrm{Al} 2024$

(3): Al 6061

FIgURE 12: Potentiodynamic polarization curves of $\mathrm{Al}$ alloys in the Red Sea water at $25^{\circ} \mathrm{C}$ and $60^{\circ} \mathrm{C}$ temperature. 

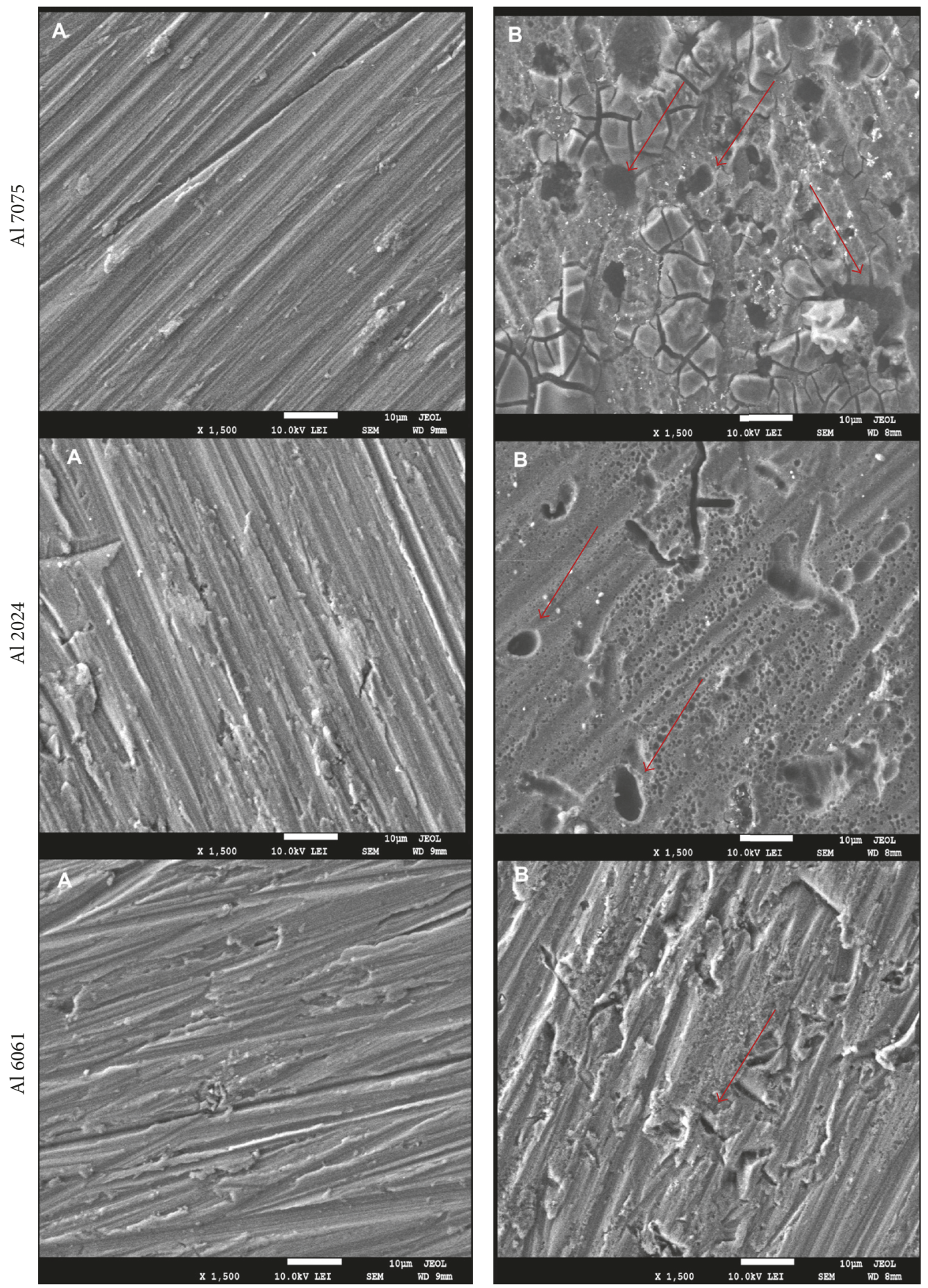

Figure 13: SEM images of $\mathrm{Al} 7075, \mathrm{Al} 2024$, and $\mathrm{Al} 6061$ "A" before and "B" after being immersed in the Red Sea water for 5 weeks. The arrows indicate the pits.

et al. [40] reported nearly the same behavior of $\mathrm{MgZn}_{2}$ (one of the constituent particles population in $\mathrm{Al}$ 7075) with temperature in chloride solution; the electrochemical response of $\mathrm{MgZn}_{2}$ did not show great variation with temperature from $25^{\circ} \mathrm{C}$ to $60^{\circ} \mathrm{C}$, so we predicted that $\mathrm{MgZn}_{2}$ particle has a very important effect on the overall behavior of $\mathrm{Al} 7075$.
3.3. Surface Characterization (SEM and EDS). Figure 13 depicts SEM images of the studied alloys (Al 7075, Al 2024, and $\mathrm{Al}$ 6061, resp.) "A" before and "B" after immersion in the Red Sea water for five weeks. Before taking images, sample A was abraded and treated as referred in Section 2.1 and sample $\mathrm{B}$ was pickled in nitric acid to remove corrosion products. SEM images "A" display noncorroded surfaces with scratches 


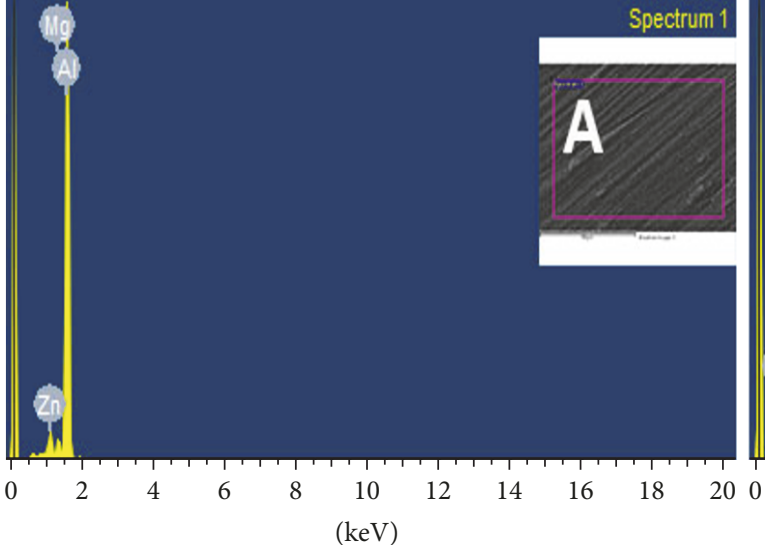

Full scale 4044 cts cursor: 0.000

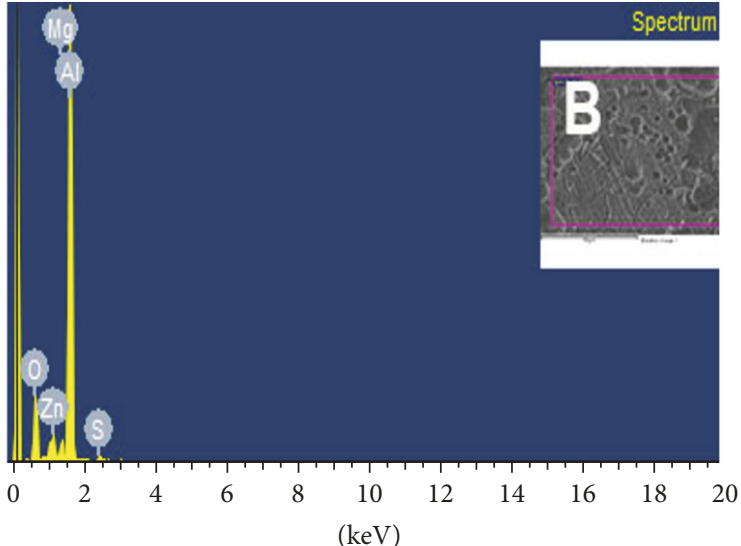

Full scale 3224 cts cursor: 0.000

\begin{tabular}{lccccc}
\hline Atomic\% & $\mathrm{Al}$ & $\mathrm{O}$ & $\mathrm{Mg}$ & $\mathrm{Zn}$ & $\mathrm{S}$ \\
\hline $\mathrm{A}$ & 94.46 & - & 2.83 & 2.70 & - \\
$\mathrm{B}$ & 64.68 & 30.21 & 2.32 & 1.51 .636 & 1.16 \\
\hline
\end{tabular}

FIGURE 14: EDS results of Al 7075 "A" before and "B" after being immersed in the Red Sea water for 5 weeks.

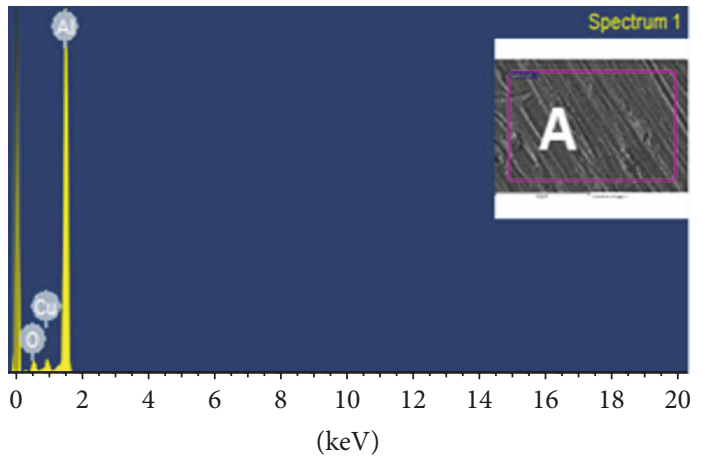

Full scale 4127 cts cursor: 0.000

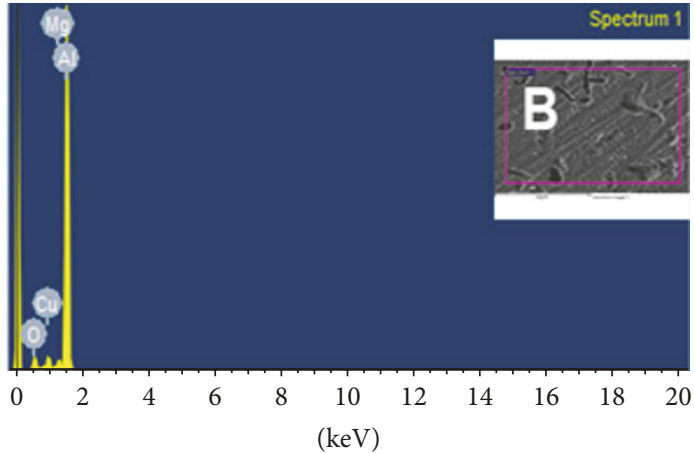

Full scale 4198 cts cursor: 0.000

\begin{tabular}{lcccc}
\hline Atomic\% & $\mathrm{Al}$ & $\mathrm{O}$ & $\mathrm{Cu}$ & $\mathrm{Mg}$ \\
\hline $\mathrm{A}$ & 88.41 & 9.50 & 2.09 & - \\
$\mathrm{B}$ & 85.65 & 10.74 & 2.05 & 1.56 \\
\hline
\end{tabular}

FIgURE 15: EDS results of $\mathrm{Al} 2024$ "A" before and "B" after being immersed in the Red Sea water for 5 weeks.

due to polishing. Heterogeneous nature of aluminum alloys surfaces is evident by images " $A$ ". SEM images " $B$ " show damaged surfaces due to localized attack by the Red Sea water. $\mathrm{Al} 6061$ is less damaged than other alloys. Pits can be observed in $\mathrm{Al} 7075$ and $\mathrm{Al} 2024$ images. Flakes of corrosion products are shown in $\mathrm{Al} 7075$.

For EDS results represented in Figures 14-16, two different samples of the same alloy type were detected by EDS to analyze the elements present on the whole surface (A, noncorroded sample, and B, corroded sample); so, it is thought that EDS analysis lost some degree of precision. In general, $\mathrm{Al}$ percent decreased after immersion in seawater and oxygen increased. Copper content in $\mathrm{Al} 2024$ was almost constant before and after corrosion because of the cathodic nature of the copper and $\mathrm{Cu}$-rich particles with respect to alloy matrix. S peak was observed in Al 7075 spectra after corrosion. Appearance of S on Al 7075 after corrosion gives an indication of the contribution of bacteria in corrosion process as SRB. Sulfate reducing bacteria exist in seawater and obtain their energy by reducing sulfate ions to highly corrosive sulfide ions such as $\mathrm{S}^{2-}, \mathrm{HS}^{-}$, or $\mathrm{H}_{2} \mathrm{~S}$ or metal sulfides which can accelerate the electrochemical reaction of corrosion. Previous literature proved that SRB induces pitting corrosion for $\mathrm{Al} 7075$ and $\mathrm{Al} 2024$ [18].

\section{Conclusion}

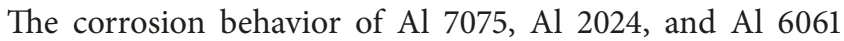
was investigated in this research and the results revealed the following: 


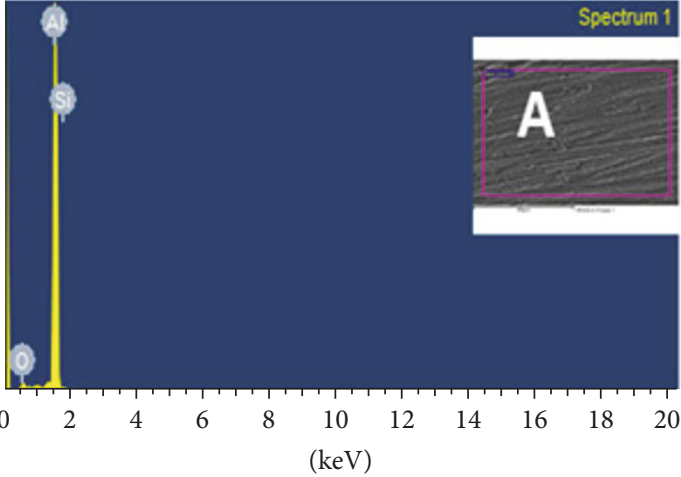

Full scale 4536 cts cursor: 0.000

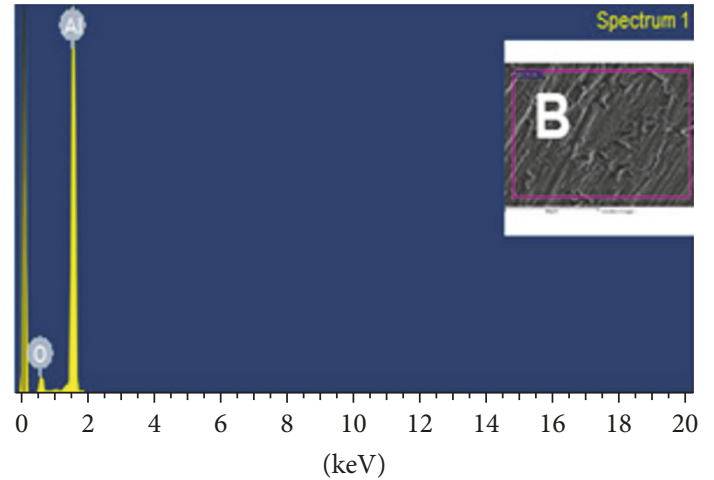

Full scale 4398 cts cursor: 0.000

\begin{tabular}{lccc}
\hline Atomic\% & $\mathrm{Al}$ & $\mathrm{O}$ & $\mathrm{Si}$ \\
\hline $\mathrm{A}$ & 94.07 & 5 & 0.94 \\
$\mathrm{~B}$ & 85.33 & 14.67 & - \\
\hline
\end{tabular}

Figure 16: EDS results of $\mathrm{Al} 6061$ "A" before and "B" after being immersed in the Red Sea water for 5 weeks.

(i) The corrosion rates of $\mathrm{Al}$ alloys decreased with time and the weight loss data for 32 weeks were consistent with the bimodal model.

(ii) Increase in temperature led to an increase in both anodic and cathodic current density and a decrease in corrosion potential. Lowering corrosion potential was associated with an increase in breakdown potential which resulted in expanding the passivity region with temperature

(iii) All the alloys suffered from pitting corrosion and the most corroded alloy was Al 7075. Al 6061 showed the highest corrosion resistance at all the immersion times.

\section{Conflicts of Interest}

The authors declare that there are no conflicts of interest regarding the publication of this article.

\section{Acknowledgments}

The authors are immensely grateful to Professor Robert E. Melchers, University of Newcastle, for his comments on WL data. He agreed with us that the data are consistent with bimodal model and explained the reason for the observation of the bimodal model with short-immersion time as we wrote in kinetic study section.

\section{References}

[1] A. Sverdlin, "Physical metallurgy and processes," in Handbook of Aluminum, G. E. Totten and D. S. MacKenzie, Eds., vol. 1, pp. 1-32, CRC Press, New York, NY, USA, 2003.

[2] K. A. Chandler, Marine and Offshore Corrosion, Marine Engineering Series, Elsevier, Oxford, UK, 2014.
[3] R. L. Reuben, Materials in Marine Technology, Springer-Verlag, London, UK, 1994.

[4] J. E. Hatch, Ed., Aluminium: Properties and Physical Metallurgy, ASM International, Ohio, USA, 1984.

[5] J. R. Davis, Ed., Alloying: Understanding the Basics, ASM International, Ohio, USA, 2001.

[6] R. Javaherdashti, Micrbiologically Influenced Corrosion, Springer-Verlag, London, UK, 2008.

[7] E. McCafferty, Introduction to Corrosion Science, SpringerVerlag, NewYork, NY, USA, 2010.

[8] J. R. Davis, Ed., Corrsion of Aluminum and Aluminum Alloys, ASM International, Ohio, USA, 1999.

[9] A. E. Hughes, N. Birbilis, J. M. C. Mol, S. J. Garcia, X. Zhou, and G. E. Thompson Z, Recent Trends in Processing and Degradation of Aluminium Alloys, Z. Ahmad, Ed., In Tech, Rijeka, Croatia, 2011.

[10] T. H. Muster, A. E. Hughes, and E. G. Thompson, Copper Distributions in Aluminium Alloys, Nova, New York, NY, USA, 2009.

[11] N. L. Sukiman, X. Zhou, N. Birbilis et al., "Aluminum Alloys: New Trends in Fabrication and Application,” Z. Ahmad, Ed., pp. 47-97, In Tech, Rijeka, Croatia, 2012.

[12] J. Soltis, "Passivity breakdown, pit initiation and propagation of pits in metallic materials-review," Corrosion Science, vol. 90, pp. 5-22, 2015

[13] Z. Szklarska-Smialowska, "Pitting corrosion of aluminum," Corrosion Science, vol. 41, no. 9, pp. 1743-1767, 1999.

[14] I. L. Muller and J. R. Galvele, "Pitting potential of high purity binary aluminium alloys-I. AlCu alloys. Pitting and intergranular corrosion," Corrosion Science, vol. 17, no. 3, pp. 179-193, 1977.

[15] R. Baboian, Ed., Corrosion Tests and Standards, ASTM International, West Conshohocken, PA, USA, 2005.

[16] D. A. Shifler, T. Tsuru, P. M. Natishan, and S. Ito, Eds., Corrosion in Marine And Saltwater Environment II, The Electrochemical Society, Nueva Jersey, USA, 2005.

[17] I.-W. Huang, B. L. Hurley, F. Yang, and R. G. Buchheit, "Dependence on temperature, $\mathrm{pH}$, and $\mathrm{Cl}$ - in the uniform corrosion of aluminum alloys 2024-T3, 6061-T6, and 7075-T6," International Journal of Corrosion, vol. 199, pp. 242-253, 2016. 
[18] E. Ghali, Corrosion Resistance of Aluminum and Magnesium Alloys, John Wiley \& Sons, Hoboken, NJ, USA, 2010.

[19] D. Ornek, A. Jayaraman, T. K. Wood, Z. Sun, C. H. Hsu, and F. Mansfeld, "Pitting corrosion control using regenerative biofilms on aluminium 2024 in artificial seawater," Corrosion Science, vol. 43, no. 11, pp. 2121-2133, 2001.

[20] R. Rosliza, H. B. Senin, and W. B. W. Nik, "Electrochemical properties and corrosion inhibition of AA6061 in tropical seawater," Colloids and Surfaces A: Physicochemical and Engineering Aspects, vol. 312, no. 2-3, pp. 185-189, 2008.

[21] V. S. Sinyavskii and V. D. Kalinin, "Marine corrosion and protection of aluminum alloys according to their composition and structure," Protection of Metals, vol. 41, no. 4, pp. 317-328, 2005.

[22] H. Ezuber, A. El-Houd, and F. El-Shawesh, "A study on the corrosion behavior of aluminum alloys in seawater," Materials and Corrosion, vol. 29, no. 4, pp. 801-805, 2008.

[23] A. Aballe, M. Bethencourt, F. J. Botana, M. J. Cano, and M. Marcos, "Localized alkaline corrosion of alloy AA5083 in neutral 3.5\% NaCl solution," Corrosion Science, vol. 43, no. 9, pp. 1657-1674, 2001.

[24] A. H. Al-Moubaraki, A. Al-Judaibi, and M. Asiri, "Corrosion of C-steel in the red sea: effect of immersion time and inhibitor concentration," International Journal of Electrochemical Science, vol. 10, no. 5, pp. 4252-4278, 2014.

[25] ASTM, G1-03 (2017)el, Standard Practice for Preparing, Cleaning, and Evaluating Corrosion Test Specimens, ASTM International, West Conshohocken, PA, USA, 2017.

[26] A. U. Malik, S. Ahmad, I. Andijani, and S. Al-Fouzan, "Corrosion behavior of steels in Gulf seawater environment," Desalination, vol. 123, no. 2-3, pp. 205-213, 1999.

[27] I. O. Wallinder and C. Leygraf, "Seasonal variations in corrosion rate and runoff rate of copper roofs in an urban and a rural atmospheric environment," Corrosion Science, vol. 43, no. 12, pp. 2379-2396, 2001.

[28] G. S. Frankel, "Pitting corrosion of metals: a review of the critical factors," Journal of The Electrochemical Society, vol. 145, no. 6, pp. 2186-2198, 1998.

[29] G. Tammann, Lehrbuch der Metallographie, Leopold Voss, Leipzig, Germany, 2nd edition, 1923.

[30] R. E. Melchers, "Bi-modal trend in the long-term corrosion of aluminium alloys," Corrosion Science, vol. 82, pp. 239-247, 2014.

[31] R. E. Melchers, "Time dependent development of aluminium pitting corrosion," Advances in Materials Science and Engineering, vol. 2015, Article ID 215712, 2015.

[32] M. Morcillo, S. Feliu, and J. Simancas, "Deviation from bilogarithmic law for atmospheric corrosion of steel," British Corrosion Journal, vol. 28, no. 1, pp. 50-52, 1993.

[33] J. H. Wang, F. I. Wei, Y. S. Chang, and H. C. Shih, "The corrosion mechanisms of carbon steel and weathering steel in SO2 polluted atmospheres," Materials Chemistry and Physics, vol. 47, no. 1, pp. 1-8, 1997.

[34] B. Yi, D. Lin, Y. Chen, N. Dai, X. Du, and J. Zhang, "Effect of $\mathrm{Cl}$ - and SO42- on corrosion behavior of reinforcing steel in simulated concrete pore solutions," Corrosion Science and Protection Technology, vol. 28, no. 2, pp. 97-102, 2016.

[35] G. Sahoo and R. Balasubramaniam, "On the corrosion behaviour of phosphoric irons in simulated concrete pore solution," Corrosion Science, vol. 50, no. 1, pp. 131-143, 2008.

[36] Z. Zhao and G. S. Frankel, "On the first breakdown in AA7075T6," Corrosion Science, vol. 49, no. 7, pp. 3064-3088, 2007.
[37] L. Garverick, Ed., Corrosion in the Petrochemical Industry, ASM intrernationa, Ohio, USA, 1994.

[38] M. Belkhaouda, L. Bazzi, R. Salghi et al., "Effect of the heat treatment on the behaviour of the corrosion and passivation of 3003 aluminium alloy in synthetic solution," Journal of Materials and Environmental Science, vol. 1, no. 1, pp. 25-33, 2010.

[39] Q. Meng and G. S. Frankel, "Effect of Cu content on corrosion behavior of 7xxx series aluminum alloys," Journal of The Electrochemical Society, vol. 151, no. 5, pp. B271-B283, 2004.

[40] M. K. Cavanaugh, J.-C. Li, N. Birbilis, and R. G. Buchheit, "Electrochemical characterization of intermetallic phases common to aluminum alloys as a function of solution temperature," Journal of The Electrochemical Society, vol. 161, no. 12, pp. C535C543, 2014. 


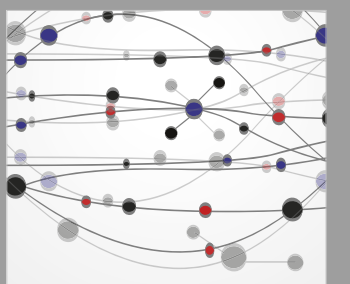

The Scientific World Journal
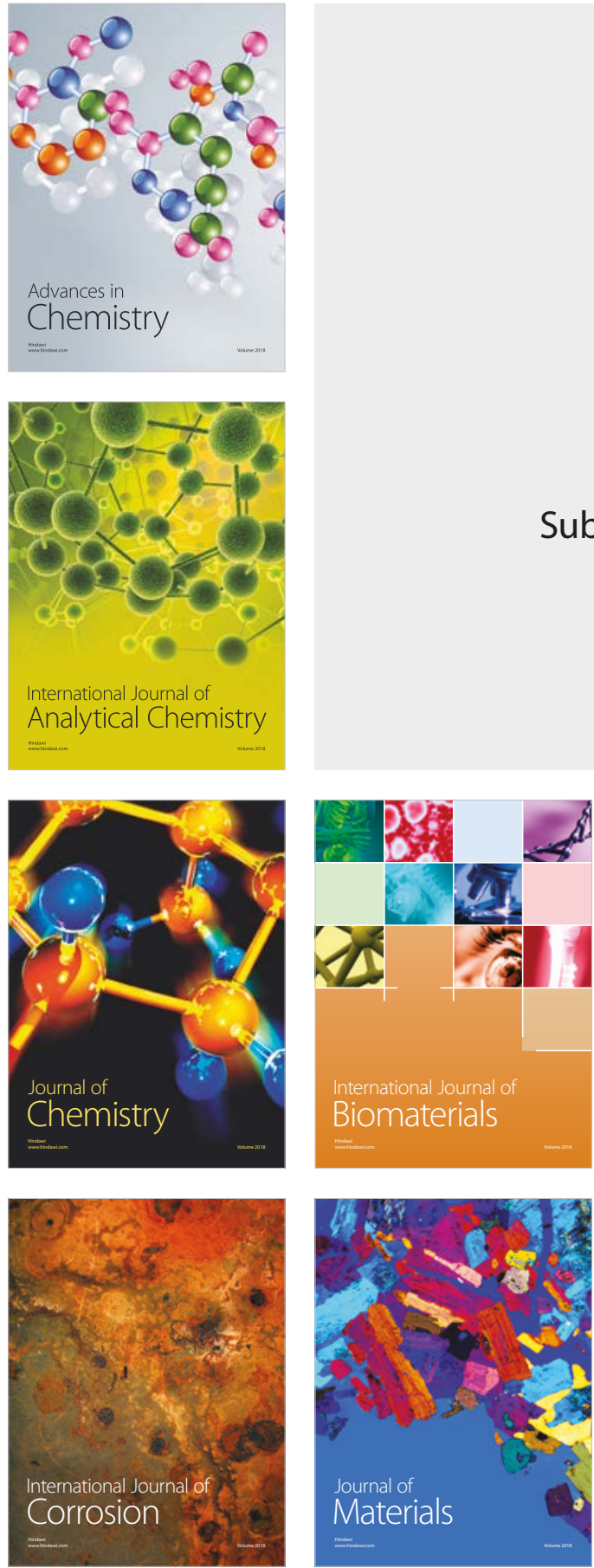

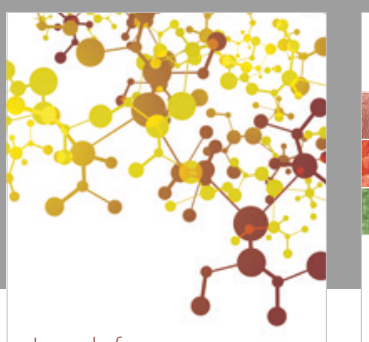

Journal of

Applied Chemistry
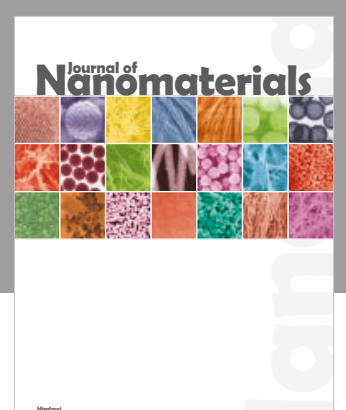

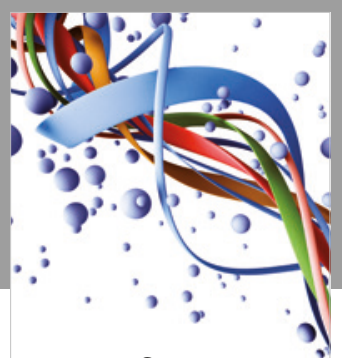

Scientifica

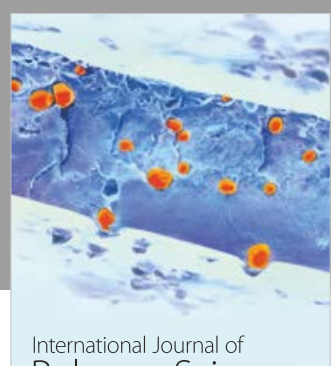

Polymer Science

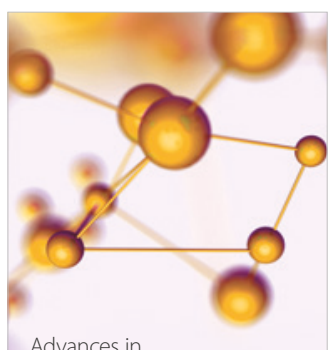

Physical Chemistry
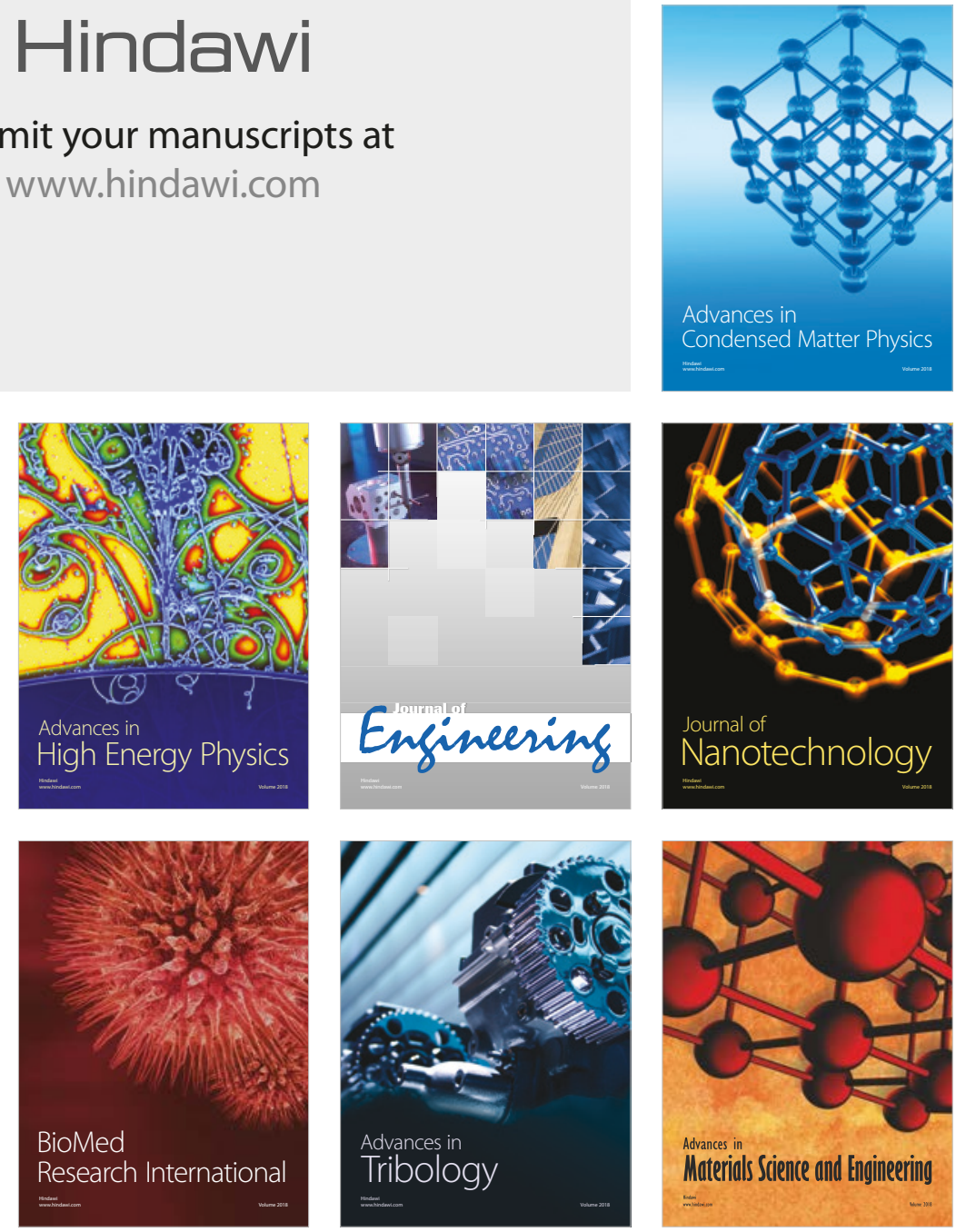